DOI https://doi.org/10.30525/978-9934-26-180-0-29

\title{
ХРОНОТОП ЯК МАРКЕР МОДИФІКАЦІЇ БІХЕВІОРИСТИЧНОЇ СТРАТЕГІЇ ІНДИВІДА В РОМАНІ ЛЮКО ДАШВАР «НА ЗАПАХ М'ЯСА»
}

\author{
Телець Ю. В. \\ аспірант IV року навчання за спеціальністю 035 - Філологія \\ Київький університет імені Бориса Грінченка \\ м. Київ, Украӥна
}

Хронотоп як формотворча категорія твору лежить в основі художніх образів і являє собою додатковий образ, що сприймається на асоціативноінтуїтивному рівні через сукупність просторових замальовок, часових символів та метафор [3, с. 279]. Будучи жанроутворюючим елементом твору, часопростір моделює поліваріативні зв'язки картини світу: часові, етичні, соціальні тощо. Зокрема, Люко Дашвар репрезентує моральноціннісні характеристики й поведінку своїх персонажів завдяки відповідному типу простору.

У романі «На запах м'яса» авторка протиставляє лінеарний тип простору ненаправленому. Перший притаманний місту й мегаполісу, що вимагають від своїх жителів постійного руху та активної діяльності. Так, рідний Генічеськ вчить Майю з самого малку заробляти на свої мрії та допомагати матері вилазити з тенет бідності: «Коли сумувати? Усім тут одна турбота: влітку копійку 3 курортників вицідити, узимку до наступного сезону облуплені квартири підготувати», «Прилаштувалася до приморського ресторанчика - i офіціантка, i посудомийка, i прибиральниця, як треба» [4, с. 97]. Але не зважаючи на такий графік роботи та спроби розпочати самостійне доросле життя, простір курортного містечка залишається в свідомості Гілки місцем формування цілей на майбутнє та міцної дружби з дівчатами. Наївне світобачення та відсутність життєвого досвіду відкривають перед провінціалками чарівний (уявний) світ у вигляді мегаполісу. На думку дівчат, Київ - це територія втілення усіх бажань та незліченних можливостей, і оскільки «тут шансів нема», героїні одна за одною змінюють «свій» простір на «чужий».

Імпульсивні спроби освоїтись з чужим направленим простором («Бо в Майки справ по горло. Уперше після вступу група першокурсників із гуртожитку збиралася в центр міста: Хрещатик подивитись, себе показати...», «спішила напитися столичним життям», «недосипала, аби 
повеселитися з друзями на вечірці» [4, с. 109]) забирають життєву енергію та виснажують Майю, тому вже зовсім скоро дівчина «до Києва охолола». Задовольнивши базові природні бажання, розчарована реаліями сучасного міського життя Майя, внаслідок дії ряду інгібуючих факторів, вирішує повторно змінити локацію для проживання. Приймаючи тактику ескапізму та роль «відлюдника», дівчина надає пріоритет чужому нерухомому простору - Лупиному хутору.

Люко Дашвар використовує локус села не лише для демонстрації зміни психологічного стану героїні, але й для створення класичної опозиції «село-місто». Капулетці та Лупин хутір, перебуваючи в стагнації, переживають економічну та духовну кризу. Проблеми 3 працевлаштуванням, відірваність від світу, обмежений простір комунікації, брак коштів, відсутність сучасних технологій - це лише частина кола порушених проблем у творі, що завуальовані в художніх деталях. Проте головною $є$ не сама сільська місцевість, а навколишнє середовище, природа, що виконує релаксаційну функцію та функцію катарсису, тобто духовного очищення від негативних емоцій, думок, настроїв.

Недаремно Майя з'являється на хуторі саме взимку. Зима символізує перепони у житті головної героїні, іiі зневіру в людях, бажання вмерти наодинці. Проте фрагментарні картини пейзажу ілюструють настроєву зміну Майї, іiі підсвідоме задоволення від побаченого: «Майка вийшла на tанок, роззирнулася зачудовано - мамо рідна! Новий сніг вкрив усе навкруги...», «Над головою небеса блакиттю розстаралися. I без краю то, без краю. Наче боже око стежить пильно, аби ніхто не сіпнувся те диво зіпсувати» [4, с. 26], «Сонце світить, сніг хвилями, сосни розділовою лінією між небесами й землею. Повітря - пий! Краса...» [4, с. 62]. Відповідного символічного значення набуває й кольорова семантика, адже білий колір в психології асоціюється з чистотою та невинністю, в релігії - з божеством, благом, життям, світлом. Закономірним є початок одужання героїні, коли вона знаходить у собі сили привести до ладу занедбану хату на хуторі та навіть намагається відшукати позитивні сторони свого перебування за межами міської цивілізації: «...вперше за три дні нового життя уважно обстежила власну хату. Хіба були колинебудь у неї такі хороми? [...] А тут - цілий світ... Захопилася, потягла ноги по кімнатках» [4, с. 54].

Дім та його внутрішній простір стають захисним чинником від загроз, що надходять із зовнішнього світу у вигляді спогадів, роздумів, сусідів, незнайомців тощо (« - Моя барлога... - розтривожилася, затяглася, ганчірку знайшла, почала пил збирати. - Ніхто сюди не поткнеться!» [4, с. 55]). Архетип будинку як просторова міфологема пов'язаний 
3 образом Космосу, це своєрідна модель світобачення індивіда. Власне тому Майя хоче намалювати ластівок на стелі, вирішує, як розставляти старі меблі та починає хазяйнувати. Оселя стала не лише притулком від небезпек, але й надала відчуття свободи, сенсу існування, нового способу задоволення від життя через працю : «...попри безпорадність, самотність, спустошеність і хронічний біль у животі, Майка почувалася захищеною. Дерев'яний теплий дім дихав разом із господинею, відкривав свої секрети...» $[4$, с. 68]. Проте повністю означити кордони між «своїм» та «чужим» простором не вдається. Майя власноруч розбирає огорожу, що відмежовує іiї подвір'я від інших («Повалила огорожу, відривала дошки, звалювала на купу в маленькій кімнатці навпроти вхідних дверей» $[4$, c. 58]) i, таким чином, дозволяе незнайомим людям втручатися до іiі обійстя без жодних перепон. Ще одним способом втручання в Майчин простір є вікно, яке дівчина так і не завісила, що дало змогу односельчанам стати свідками іiі життєвої історії. Проте кожен користується ситуацією по-своєму: Уляна, сусідка по хаті, стає очевидцем тілесної втіхи дівчини 3 Горохом та залишає побачену таємницю при собі; Микола Галаган, узрівши оголену Майю у вікні, інтерпретує побачену картину відповідно до провінційних стереотипів, вважаючи дівчину розпусною; Толя Горох використовує вікно, як засіб спостереження за настроєм та поведінкою дівчини, адже не хоче її бентежити та завдавати клопоту.

Отже, хронотоп як формотворча категорія сюжету роману Люко Дашвар «На запах м'яса» визначає художню єдність літературного твору в його ставленні до дійсності; дозволяє комбінувати різні часові та просторові характеристики; моделює ланцюжок асоціацій у свідомості читача, завдяки чому пов'язує твір зі світоглядними позиціями реципієнта; виступає одним із основних способів характеристики персонажів, оскільки надає додаткову інформацію. Часопростір та герої, які в ньому перебувають, вступають у тісний взаємозв'язок, що призводить до постійних змін фізичного та духовного стану персонажів твору.

\section{Література:}

1. Бахтин М. М. Формы времени и хронотопа в романе. Очерки по исторической поэтике. Вопросы литературы и эстетики. М. М. Бахтин. Москва, Худож. лит., 1975. С. 234-407.

2. Белімова Т. В. Образ села в романах Марії Матіос і Люко Дашвар. Науковий вісник Миколаївського державного університету імені В. О. Сухомлинського. Серія: Філологічні науки. 2015. № 2. С. 15-19. 
3. Веденкова Е. С. Исследование художественного пространствавремени: вопросы методологии. Вестник ТГУ. 2011. № 12. С. 279-284.

4. Дашвар Л. На запах м'яса : роман. Харків, Книжковий Клуб «Клуб Сімейного Дозвілля», 2016. 368 с.

5. Свириденко О. Опозиція село / місто в організації художнього простору прози Люко Дашвар. Теоретична $i$ дидактична філологія. 2015. Вип. 20. С. 89-98. 